\title{
How Can Science Become a Subject for Everyone?
}

\author{
Mette Fredslund Andersen \\ Metropolitan University College
}

\begin{abstract}
Some non-mainstream students can find the subject of science to be exclusionary. This action research programme investigates how science teachers can develop science teaching in form levels 4-6 to include marginalized students and enable them to become active participants in the community of practice in science classrooms. The programme consisted of two cycles. The first cycle aimed at identifying problems concerning marginalized students in science classrooms. The second cycle aimed at exploring as well as testing new approaches in inclusive practices in the science classroom. The project results suggested that some ways forward could include to clarify the goals and content of science teaching and to scaffold inquiry-based work and fieldwork.
\end{abstract}

\section{Introduction}

The idea of inclusive education is a high priority in the Danish primary and secondary school system in 2015. The present focus on inclusion emphasizes the discussion concerning whether teaching in various school subjects matches a diverse student population. In general, the natural sciences are presented in a manner that is not accessible or meaningful to all students [1]. It is, e.g., a well-documented fact that science classes pose challenges for many bilingual students and students from low socioeconomic backgrounds [2].

At the same time a maxim of science didactics is that science must be for everyone:

"Science for all. This phrase has been central to reform efforts in the science education community for more than a decade. But despite early attempts to raise awareness of the needs and promises of a growingly diverse student population, science seems to continue to belong to a selected few rather than all of our students." [3]
The article "Teaching Science to Learners With Special Needs" [4] sums up some of the research in this field. According to this research, some effective avenues for students with special needs include guided inquiry, hands-on science and a multimodal teaching approach, as well as curriculum materials modified to align with students' capacity and some alternative ways of managing student behaviour. Sarah J. Watt et al. [5] emphasize the use of a more structured inquiry approach that utilizes explicit enhancements as an inclusive practice in science education. Moreover, they indicate that providing a science education that focuses on core concepts and involves ongoing formative assessment will boost learning for students with special needs. However, McGinnis [4] concludes that

"...much remains to be studied to improve science education for students with special needs in science classrooms...Therefore, a final recommendation is that teachers of science engage in practitioner research in their practices to investigate how to meet the needs of students with special needs in their science education contexts."

A number of researchers support this point, arguing that science education has gone wrong when it comes to students not in the mainstream [5]. The purpose of this action research programme has been to take up this challenge. Thus, the research question asks how science teachers can develop their classes to increase marginalized students' participation in the community of practice in the science classroom. The challenge that developing inclusive practices entails for teachers is a well-known area of research [6].

\section{Inclusive education and marginalization}

The project focuses on how science education can respond to students who are academically marginalized. The term marginalization is connected to specific situations and is understood as a non-participation that springs from the community of practice that the teaching 
endeavours to uphold [7]. It expresses a situation in which the student is cut off from opportunities to participate that would otherwise point in a meaningful direction. The project aims to transcend marginalization [8] thus enabling students to move step by step from their marginal position as non-participants and thus become legitimate participants in their science classes in other words, be included.

According to Alenkær [9] for the purposes of analysis there are two different concepts of inclusion: social and academic. In this context social inclusion occurs when students feel they are a valuable part of the personal relational community, while academic inclusion occurs when students feel they are valuable and natural contributors to the tasks involved in their school education. This project is concerned with academic inclusion, for which reason the project follows the exclusion and inclusion processes connected with the academic subject.

For students to feel like meaningful participants at school, both socially and academically, a reciprocal relationship of continual adaptation must exist between student and school. This adaptation includes changing school practice and teaching in the ways necessary to enable student participation. This was the object of this project. However, the vision of the inclusive science classroom should be understood not as a fully developed concept but as an ongoing process.

\section{Research approach and method}

The project is an action research programme that places itself within the critical utopic branch of action research, its aim being to act to change existing patterns that lead to student exclusion from science teaching and thus open up future opportunities to participate in the science education community. From this point of view action research is understood as a mutual challenge between theory and practice experience, which has been the guiding principle of the project design. The teachers involved in the programme were authorized to try out and implement new practices presumably better suited to meet marginalized students' needs. Another goal, however, was to produce knowledge about these changes by reflecting on practice.

The project chose to collaborate with five science teachers, all of whom teach form levels 4-6, because science subjects become more abstract at this phase of education, and thus more students become marginalized. All five teachers volunteered for the project and had more than five years of professional experience. The teachers taught at four different schools in a suburb of Copenhagen where the student population is diverse. The researchers involved in the project have respective backgrounds in science didactics and special education. The teachers and researchers differed in their roles and contributed different experience and knowledge to the development process. At the outset of the project, the researchers presented its focus and expected phases, but they negotiated the actual course of the project with the individual participants as it progressed. The researchers added an outsider's perspective to the practice description and contributed theoretically grounded suggestions for new forms of practice. The teachers brought their knowledge of concrete practice and a critical view to the project. The teachers and researchers collaborated on formulating the problems and setting up the experiments worked with.

Generally, the project was designed with two cycles, with the first being aimed at identifying problems and the second at seeking out and testing new possibilities.

The phases of the project were as follows:

1. Expressing specific experiences from the classes in explicit narratives

2. Observing classroom situations, conducting student questionnaires, reflecting on teachers' practice and formulating the challenges posed

3. Conceptualizing the challenges and designing a course of instruction with experiments

4. Testing and observing the experiments in practice

5. Reflecting on observations and experiences

The experiments were based on hypotheses from research literature about inclusion and science education. The researchers and teachers jointly translated and modified the theoretical knowledge so it could be interrelated with and incorporated into the local context. In fact, the teachers and researchers jointly constructed a course of instruction containing the desired innovation.

Notes taken at teacher-researcher meetings were saved. The dialogues regarding teachers' narratives and concluding reflection were recorded in audio files. Student products from the classes were also collected, kep $t$ and analyzed. The researchers conducted their first classroom observations without participation, but participated in testing the experiments. The researchers took field notes of all observations made during and after classes. For the analysis the various data were organized according to the data collection method used, reviewed several times, commented on and grouped into themes conclusively substantiated with raw data.

As triangulation the data from observations, dialogues, questionnaires and documents were compared. The data outcome was also discussed from multiple angles, and the teachers commented on the researchers' descriptions and themes, thus participating in validating them.

\section{Findings}

Two themes emerged from an analysis of the data. One concerned visible education, while the other concerned inquiry-based science classrooms.

The initial observations produced a picture of committed science teachers wishing to cover a great deal 
of subject matter. Therefore, their teaching encompassed a lot of abstract material and discussions, which a number of the academically marginalized students had difficulty putting into context and therefore became academically excluded from the class.

The courses of instruction designed for the project thus strove to cut to the bone and target teaching at central subject concepts and contexts worked with in several ways with the aim of the students' truly learning them. One of the teachers subsequently made this comment about the process:

“...Well, I've learned some things from this. Be
more precise and provide greater detail - we
can't expect them to think the same as we do. We
move in this space up here, but we have to take
ourselves all the way down there. They have to
learn it step by step - and learning takes time.”
(Teacher quotation)

As part of this effort, two experiments were specifically aimed at clarifying the content of the teaching and making its goals apparent, so that academically marginalized students could gain a clearer and more concrete sense of what the teaching concerned. The example used in this article involves a course of instruction about the human body. In the class concerned some of the academically marginalized students were bilingual. For this particular part of the course students were to learn about the heart and blood circulation.

As an experiment, the course of instruction was structured to progress very distinctly from the concrete subject matter, presented via anatomical models, to more abstract forms of representation, all clearly linked to the associated subject concepts along the way. After being presented with the goals, the students thus located their own hearts and used cardboard tubes to listen to their heartbeats. Next, they located the heart on a 3D torso model. They also studied the structure of the heart by dissecting real pig hearts, at which point subject concepts like ventricles were introduced. Subsequent dialogue about the function of the heart led to the formulation of a reading objective, and a short text about the heart and circulation was read with associated visual representation. The concepts covered were then reapplied to make a voiceover for an animation about blood circulation, a task that combined process and concept.

To conclude the course of instruction, the students did a board relay race in which they compiled all the technical concepts, after which they used them to explain what they had learned with the app Explain Everything. This app can combine pictures, text, audio, video and screen shots. The student-generated representations enabled the teacher to gain insight into the students' actual understanding and to give feedback on that basis. The digital possibilities for explaining the academic contexts orally enabled students with limited written language skills to participate.

For many of the bilingual students, the concrete teaching basis and the clear progression, which focused on concepts and the transformation between representational forms, encouraged the students' participation in the subject and their technical language development. In a subsequent interview one bilingual student said: "I just think it got a little easier for me to understand ..."

In summary, the experiments conducted in the study show that many marginalized students can participate if the teaching focuses on the core subject matter and then expands upon this material through the use of clear goals and concepts as well as continual feedback.

Another general theme in the study was the practical inquiry work in the subject. The observations of the teachers' existing practice and their narratives showed that there was a paradox connected to fieldwork and the inquiry-based science classroom. The teachers saw an inclusive potential in the inquiry-based classroom, but in practice the activities often became exclusionary. Several students had difficulties navigating the changed structure of the inquiry, as they were disturbed by other activities, did not understand the meaning of the activities and did efficiently gain educational benefits. This led to three experiments, of which one will serve as an example.

Teacher A taught a class where she was not confident taking students on field trips because some student broke rules and did not participate academically. The teacher felt, however, that the student group would benefit from fieldwork and teaching outside the classroom, where the teaching forum was authentic and concrete. Furthermore, fieldwork is a part of science. For this reason, the teacher was interested in how fieldwork could be presented and organized in a way that enabled student participation while maintaining the academic objectives.

To address this problem, the researchers drew inspiration from the article "Use of the Outdoor Classroom and Nature-Study to Support Science and Literacy Learning: A Narrative Case Study of a ThirdGrade Classroom" by Charles J. Eick [10], the paper "Inkluderende læringsmiljøer i udeskole - Et forskningsprojekt om brug af udeskole til at optimere faglig og social inklusion af elever" (Inclusive learning environments in school-based outdoor learning - A research project on the use of school-based outdoor learning to optimise academic and social inclusion of students) [11] and material from the website MinMestring.dk, among others.

The experiment put an emphasis on planning, the setting of clear goals, clear class management, a clear goal for the out-of-class study and a highly structured study of the subject in the classroom, scientific 
investigation outside the classroom and data-based writing in the classroom.

The fieldwork was implemented in a course of instruction on the components of soil. Initially, the students had to collect soil samples in their near surroundings as a basis for a dialogue about what soil really is. Later in the course of teaching they took a field trip to an area a few kilometres away to collect samples of developed soil and forest soil. A code of conduct was prepared for the trip, an excerpt of which is shown below:

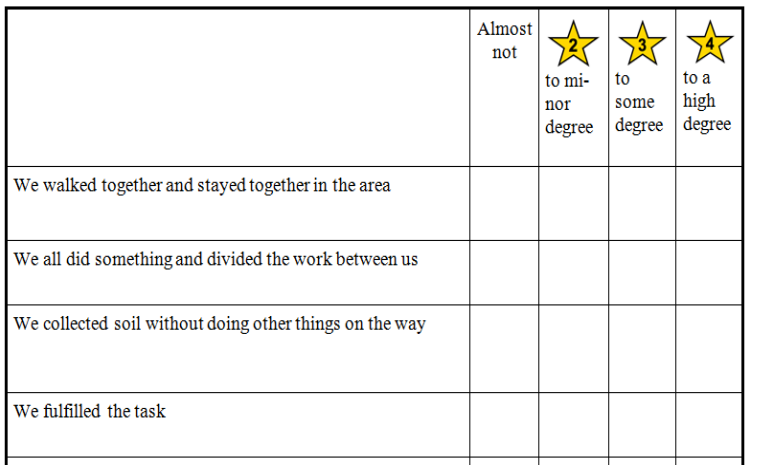

Figure 1. Excerpt of schedule

The teacher went over the form with the students in detail, so they understood and knew what was expected from them outside. After the fieldwork the groups assessed themselves and gave themselves stars, which were compared with the teacher's opinion. The first time the form was used, several students had left the group, among other faults, but there was already improvement by the second outing, and the focus points in the form of staying together and contributing to the work had become fixed points for them.

When teachers reflected on the experiment, they felt that working with the code of conduct form contributed positively to building up routines in connection with the fieldwork:

"Some of what I have taken in use is the code of conduct. That we alongside have had two parallel courses of instruction - the one about the soil, and then the one where they at first went out there (points) and then down there and then on tour .... And it is as if pointing out in detail what the expectations are somehow works to some degree or other .... I think it is something we come to neglect a little - that students have to be taught how to go on field trips - instead of our saying we cannot take them out." (Interview with teacher)

The fieldwork was thus successfully implemented in a way that involved the marginalized students. This was done by explicitly teaching students how to carry out the fieldwork and by evaluating the fieldwork on an ongoing basis in a structured course of instruction.

The other experiments also revealed that, in order for some academically marginalized students to participate and benefit educationally from hands-on activities, the work must be structured, built around routines as well as scaffolded. During another experiment students were divided into groups depending on their need for scaffolding of open inquiry assignments. Three different versions of the assignments were distributed, and the ongoing scaffolding was similarly graduated. This measure was beneficial to the marginalized students most in need of scaffolding. The most independent students also benefited from this measure, whereas the intermediate group was less motivated.

When the practical work was aptly chosen and scaffolded, many of the academically marginalized students profited from it both in the classroom and in the field. Observations, student products and students' own statements all demonstrated this. Many of the academically marginalized students benefited particularly when the practical work was very concrete and directly addressed the subject - for example, when they examined the components of soil, listened to a beating heart through a cardboard tube or encountered biodegradation in the forest. More inquiry-based activities or modelling requires additional guidance and thorough training.

\section{Discussion of results}

A focus of this study has been the practical, inquirybased work. Schools in many countries around the world are in the process of implementing this kind of work in their science classes. The findings of this project indicate that this move is a double-edged sword if these activities are to be inclusive. At the very least, we need to ask ourselves: "How much 'inquiry' should middle-level students be expected to do on their own?" If the assignments are open and truly inquiry-based, then some students will require close scaffolding and guidance to prevent them from becoming academically marginalized in their science classes.

Making a clear progression from concrete to abstract through the use of representational forms, the aforementioned example improved the bilingual students' chances of participating in the subject. At the same time, however, the linguistic focus had an exclusionary effect on students with ADHD, so their class participation was clearly below normal. That an initiative can be inclusive for some students and exclusionary for others indicates just how complex developing inclusive practices is.

The project endeavoured to work with challenges related to the subject of science and focused on academic inclusion. In practice, however, it proved impossible to maintain the distinction between academic and social inclusion. For some students, the academic obstacle 
could stem from social problems whose solutions do not necessarily lie in the way the subject is taught.

\section{Conclusion}

The study findings indicate that many academically marginalized students can participate in science classes with benefit if the teaching builds on a clear progression of core academic material, clear goals and continual feedback. Teachers can explain material to academically marginalized students through direct contact with the subject matter, fieldwork or hands-on work as well as work with the various forms of subject representation. Experiments showed that the structural organization and scaffolding of the inquiry-based classroom are crucial factors in enabling marginalized students to participate and gain a learning outcome from the activities. Observations show, and many of the marginalized students report, that benefit from hands-on activities when they are carefully contextualized, integrated and scaffolded in the classroom as well as in the field.

However, more research is required to include more students in the science classroom. There is no universal solution, but a continuous cooperation between subjectspecific teachers and teachers with a special education background as regards the identification and testing of new ways of meeting marginalized students in the classroom contributes to the development of inclusive practices in science teaching.

\section{References}

[1] Patchen, T. and Cox-Petersen, A. (2008) "Constructing Cultural Relevance in Science: A Case Study of Two Elementary Teachers". Science Education 92, (6), pp. 9941014.

[2] Jackson, J. and Ash, Q. (2012) "Achievement for All: Improving Science Performance and Closing Achievement Gaps", Journal of Science Teacher Education 23 (7), pp. 723744.

[3] Southerland S. et al. (2011) "Examining Teachers' Hurdles to "Science for All"', International Journal of Science Education 33 (16), pp. 2183-2213.

[4] McGinnis, J.R. (2013) "Teaching Science to Learners with Special Needs”, Theory Into Practice 52 (1), pp. 43-50.

[5] Watt, S. J. et al. (2013) "Promoting Inclusive Practices in Inquiry-Based Science Classrooms", TEACHING Exceptional Children 45 (4), pp. 40-48.

[6] Angelides, P. et al (2008) "The Implementation of a Collaborative Action Research Programme for Developing Inclusive Practices: Social Learning in Small Internal Networks", Educational Action Research (4), pp. 557-568.

[7] Wenger, Etienne (1998) Communities of practice: learning, meaning, and identity, Cambridge University Press.
[8] Mørck, L.L. (2007) "Young ethnic minorities in education: How to expand possibilities for learning and transcending marginalization", In Citizen City. Canada: Captus University Publications, pp. 149-159.

[9] Alenkær, R (2010), AKT ink. Inkluderende AKT-arbejde i folkeskolen. Dafolo.

[10] Eik, C. J. (2012) "Use of the Outdoor Classroom and Nature-Study to support Science and Literacy Learning: A Narrative Case Study of a Third-Grade Classroom", J Sci Teacher Educ (23), pp. 789-803.

[11] Østergaard, C. et al. (2014) Inkluderende læringsmiljøer i udeskole. Et forskningsprojekt om brug af udeskole til at optimere faglig og social inklusion af elever, NORDPRO, 23.24. oktober 2014. 